\title{
Nucleus Accumbens Modulation in Reward and Aversion
}

\author{
Anna M. Klawonn and Robert C. Malenka \\ Department of Psychiatry and Behavioral Sciences, Nancy Pritzker Laboratory, Stanford University \\ School of Medicine, Stanford, California 94305, USA \\ Correspondence: malenka@stanford.edu
}

\begin{abstract}
The nucleus accumbens (NAc) is a key node of the brain's circuitry that is responsible for translating motivation into action. It has been implicated in playing critical roles in virtually all forms of adaptive and pathological motivated behaviors. It is subject to modulation by a broad array of inputs that influence NAc activity in complex ways that are still poorly understood. Here, we briefly review current knowledge about the behavioral consequences of NAc modulation, focusing on recent studies that use novel techniques developed and implemented over the last decade.
\end{abstract}

The nucleus accumbens (NAc), a key node of mesolimbic dopamine (DA) circuitry (Volkow et al. 2017), has long been conceptualized as a critical functional connection between limbic system structures, such as the amygdala and hippocampus, and motor systems including the basal ganglia (Mogenson et al. 1980). In part because of its anatomical connectivity and the well-accepted hypothesis that NAc DA release accounts for the addictive liability of drugs of abuse (Di Chiara and Imperato 1988; Koob et al. 1998; Nestler 2005), the NAc has received attention as a crucial convergence point for neurocircuitry shaping motivated responses to salient rewarding and aversive stimuli (Volkow et al. 2017). Over the last decade, the advent of new methodologies that facilitate sophisticated identification and manipulation of neural circuits has expanded our understanding of the behavioral consequences of NAc modulation. Here, we briefly review some of the most critical of these studies, focusing on work that highlights the importance and complexity of NAc circuits. Furthermore, we attempt to underline some of the many gaps in how modulation of NAc circuit function influences adaptive and pathological motivated behaviors.

\section{NUCLEUS ACCUMBENS D1 AND D2 MSNs}

The major cell types in both the dorsal and ventral striatum are GABAergic medium spiny neurons (MSNs), which comprise $\sim 95 \%$ of the total cell population in these structures. They are commonly subdivided into two neuron populations: those that preferentially express dopamine D1 receptors (D1) and those that express dopamine D2 receptors (D2). It remains well accepted that in the dorsal striatum, D1 MSNs are key components of the so-called direct pathway as they form monosynaptic contacts with basal ganglia output nuclei, the substantia nigra pars reticulata, and the internal globus pallidus, whereas D2 MSNs are part of the indirect pathway and send axons to the external globus pallidus (Kreitzer and Malenka 2008). In classic models of basal ganglia function, increases in D1 MSN activity promote movement, whereas increases in D2 MSN activity decrease movement (Nelson and Kreitzer 2014). Although recent work makes it clear that this model is oversimplified (Parker et al. 2018), it has been heuristically useful in guiding research efforts and therapeutic interventions such as deep brain stimulation (DeLong and Benabid 2014).

In large part based on these models describing the role of the dorsal striatum in motor behaviors, NAc D1 and D2 MSNs have been considered to have different anatomical connectivity and therefore subserve different functions. NAc D1 MSNs are commonly thought to project directly to midbrain structures, primarily the ventral tegmental area (VTA), whereas NAc D2 MSNs are thought to project primarily to the ventral pallidum (VP) (Fig. 1; Nicola 2007; Kupchik and Kalivas 2017). This dichotomy applies to both the NAc shell and core, which appear to have different behavioral roles, presumably because of the different inputs that they receive (Di Chiara 2002; Ikemoto 2007; Scofield et al. 2016). Specifically, the shell is thought to be involved in tasks such as reward prediction and affective processing, whereas the core has been proposed to be responsible for acquisition of reward-cue associations and initializing motor actions and therefore may function as an intermediate between the NAc shell and the dorsal striatum. Although some recent studies exploring NAc core and shell circuits suggest some overlap in their behavioral functions (Day et al. 2007; Roitman et al. 2008; Lobo et al. 2010; Bock et al. 2013; Calipari et al. 2016), examining rewarding and aversive behaviors using simple assays such as place preference and self-administration may not detect subtle differences in core and shell functionality. Such differences may be more readily revealed using more sophisticated behavioral assays, real-time measures of neurotransmitter release or neural activity, or input-specific circuit manipulations (Gore and Zweifel

(C) 2018 Klawonn and Malenka. This article is distributed under the terms of the Creative Commons Attribution-NonCommercial License, which permits reuse and redistribution, except for commercial purposes, provided that the original author and source are credited. 

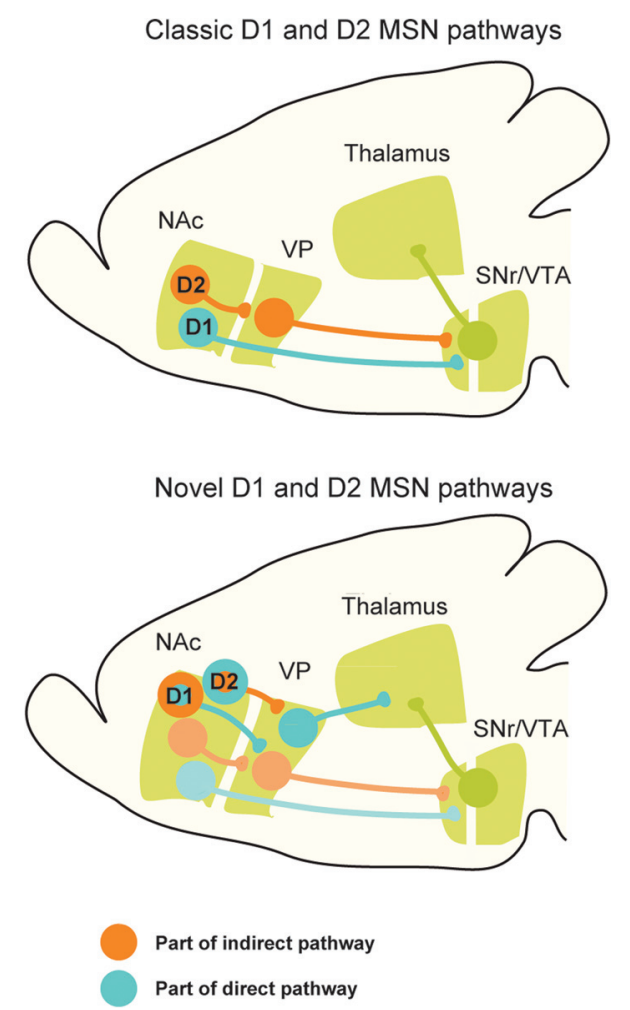

Figure 1. Schematic overview of NAc D1 and D2 MSN anatomical connectivity emphasizing the differences between the classic conceptualization of indirect and direct pathways and a novel view (based on Kupchik et al. 2015). All illustrated cells are thought to be GABAergic. (NAc) Nucleus accumbens, (VP) ventral pallidum, (SNr) substantia nigra pars reticulata, (VTA) ventral tegmental area. (Modified from Kupchik and Kalivas 2017.)

2013; Chuhma et al. 2014; Schmidt et al. 2015; Dreyer et al. 2016; Jedynak et al. 2016; Syed et al. 2016; Sackett et al. 2017; Saddoris et al. 2017).

Several studies using cell type-specific manipulations to investigate the behavioral role of NAc D1 and D2 MSNs support the idea that these two neuronal populations subserve distinct functions (Lobo et al. 2010; Kravitz et al. 2012; Bock et al. 2013; Trifilieff et al. 2013; Danjo et al. 2014; Francis et al. 2015; Calipari et al. 2016; Zhu et al. 2016). For example, optogenetic activation of NAc D1 MSNs reversed the behavioral changes caused by chronic social defeat stress, a model for depression, in susceptible mice, whereas chemogenetic inhibition of NAc D1 MSNs promoted behavioral signs of depression in resilient mice that were not initially affected by the chronic stress. In contrast, repeated activation of NAc D2 MSNs induced social avoidance following subthreshold social defeat stress (Francis et al. 2015). Furthermore, the synaptic adaptations and changes in intrinsic excitability caused by drugs of abuse or stress are different in NAc D1 and D2 MSNs in a manner that appears to contribute to the behavioral adaptations caused by these chronic manipulations (Russo et al. 2010; Lüscher and Malenka 2011; Russo and Nestler 2013; Francis and Lobo 2017).

However, as is the case with the simple rate model for the role of basal ganglia direct pathway and indirect path- way function in motor behavior, the simple dichotomy between the roles of NAc D1 and D2 MSNs is being questioned. Recent work found that a substantial proportion of NAc core D1 MSNs project to neurons in the dorsal $\mathrm{VP}$, which is the anatomical target of the traditionally defined indirect pathway (Kupchik et al. 2015). Overall, $\sim 50 \%$ of the recorded VP neurons received D1 MSN input, whereas $\sim 90 \%$ received D2 MSN input. This study further showed that D2 MSNs target a group of VP neurons directly innervating the thalamus. Hence, D1 MSNs projecting to the dorsal VP may function in an "indirect pathway"-like manner, whereas D2 MSNs may function in a "direct pathway"-like manner (Fig. 1; Kupchik and Kalivas 2017). NAc shell D1 and D2 MSNs also both project to VP cells, which in turn innervate the VTA. Surprisingly, however, the behavioral roles of NAc D1 MSN-VP synapses and NAc D2 MSN-VP synapses following chronic cocaine administration appear to differ (Creed et al. 2016; Heinsbroek et al. 2017).

The specific behavioral roles of NAc D1 and D2 MSNs are also beginning to be elucidated based on the additional targets to which they project (e.g., lateral hypothalamus) and the NAc subregions in which they are located (AlHasani et al. 2015; O'Connor et al. 2015; Gibson et al. 2018; Yang et al. 2018). An additional, potentially important distinction in the organization of both the dorsal striatum and NAc, which has not been adequately analyzed, is the presence of so-called patch-matrix compartments (also termed striosome-matrix compartments) (Gerfen et al. 1987; Gerfen 1992; Zahm and Brog 1992; Crittenden and Graybiel 2011; Watabe-Uchida et al. 2012; Brimblecombe and Cragg 2017). MSNs in patch compartments preferentially express $\mu$-opioid receptors, a molecular distinction that seems likely to have functional importance. As discussed further below, clearly we are in the early stages of understanding the detailed cellular architecture of the NAc, in terms of subregional input-output organization of its major constituent cell types and their myriad behavioral roles.

\section{EXCITATORY INPUTS TO NUCLEUS ACCUMBENS}

NAc MSNs do not generate action potentials spontaneously, and therefore increases in their activity are driven by excitatory synapses from a range of brain regions (O'Donnell et al. 1999; Scofield et al. 2016). Historically, inputs from the prefrontal cortex (PFC), ventral hippocampus (vHip), and basolateral amygdala (BLA) have received the most attention. However, recent work using the cell type-specific monosynaptic rabies virus tracing technique has revealed a large number of additional brain areas that synapse with NAc MSNs (Barrientos et al. 2018). The advent of optogenetics facilitated behavioral tests of the consequences of activating the major inputs to the NAc, with the somewhat surprising result that activation of inputs from either PFC, vHip, or BLA inputs is reinforcing (Stuber et al. 2011; Britt et al. 2012; Prado et al. 2016; Otis et al. 2017). These findings supported the provocative no- 
tion that the specific input driving NAc MSN activity may be functionally irrelevant, despite the different behavioral roles of the brain areas providing the inputs. However, recently it has been reported that activation of glutamatergic inputs from the paraventricular nucleus (PVN) of the thalamus causes aversion, and that these inputs, like the PFC, vHip, and BLA inputs, appear to synapse on both NAc D1 and D2 MSNs (Zhu et al. 2016). This finding poses problems for the simple notion that activation of any excitatory input to the NAc, independent of its source, is reinforcing and points out the critical importance of understanding the connectivity of individual populations of NAc D1 and D2 MSNs based on their anatomical localization, the targets to which they project, and their molecular properties (e.g., patch vs. matrix).

Conceptually, it makes sense that excitatory inputs from different brain regions will subserve different behavioral functions. In support of this idea, the NAc MSN synaptic adaptations caused by drugs of abuse, primarily cocaine, differ depending on the source of the presynaptic inputs (Lüscher and Malenka 2011; Lüscher 2016). For example, recordings from MSNs in the NAc shell suggest that repeated cocaine administration followed by withdrawal leads to synaptic strengthening of some inputs and weakening of others (Pascoli et al. 2011, 2014; Britt et al. 2012; Ma et al. 2014; MacAskill et al. 2014; Creed et al. 2015; Terrier et al. 2016; Barrientos et al. 2018). Furthermore, as mentioned above, the drug- and stress-induced synaptic adaptations in the NAc depend on whether D1 or D2 MSNs are examined. Evidence that these experience-dependent synaptic changes are functionally important is provided by experiments in which optogenetic reversal of drug-induced synaptic changes rescue behavioral adaptations caused by the drug experience (Pascoli et al. 2011, 2014; Bock et al. 2013; Ma et al. 2014; Creed et al. 2015). Based on these findings, it is possible to generate hypotheses concerning the specific NAc synaptic and circuit adaptations that contribute to rodent models of addiction and depression (Lüscher 2016; Francis and Lobo 2017).

Surprisingly, however, in contrast to the notion that different inputs to the NAc subserve different functions, a recent imaging study using GCaMP to measure activity in excitatory inputs to the NAc from BLA, vHip, and thalamus found that activity patterns, during a discriminant stimulus operant reward-seeking task with food as the reward, varied along the rostrocaudal axis of the NAc (Reed et al. 2018). Furthermore, similar decreases in activity in all three inputs in the rostral NAc shell occurred during feeding, whereas optogenetic inhibition of each pathway individually promoted food consumption. These results suggest that the anatomical location of inputs within the NAc may be as important as the source of the inputs.

The results obtained over the last decade using modern tools of circuit neuroscience offer abundant evidence in support of the notion that the NAc is a critical node of the circuitry that translates motivation into action. However, these results also reveal how little we know about the detailed circuit connectivity by which NAc neurons contribute to behavior. Just a few of the critical questions that need to be addressed for a more sophisticated understand- ing of how NAc circuit adaptations contribute to behavioral flexibility include: Do individual NAc MSNs receive inputs from all of the major excitatory projection regions or is there functionally important cell-to-cell variability? Are there functionally important differences in the inputs to NAc D1 versus D2 MSNs? How does the detailed connectivity of D1 and D2 MSNs differ in the various subregions of the NAc (e.g., lateral shell, medial shell) and along the NAc rostrocaudal axis, which has been suggested to have powerful influences on appetitive versus aversive behaviors (Reynolds and Berridge 2008)? Do inputs to NAc MSN show functionally important subcellular topography such that some consistently synapse on more distal dendrites and others on more proximal dendrites? How heterogeneous are the outputs of individual NAc MSNs, and do these outputs show regional variation? In addition to now standard tools such as optogenetics and monosynaptic rabies virus tracing, incorporating new methods such as dual-eGRASP (Choi et al. 2018) will be critical to the development of a more sophisticated and comprehensive understanding of the complex circuitry in which the NAc is embedded to facilitate the translation of motivation into action.

\section{DOPAMINE ACTION IN THE NUCLEUS ACCUMBENS}

In addition to being influenced by direct glutamatergic inputs from a wide range of brain regions, the NAc is the target of numerous neuromodulatory systems with important roles in cognition and motivated behaviors. Almost 50 years ago, the anatomical demonstration that the NAc is a major target for midbrain VTA DA neurons (Ungerstedt 1971) led to a large body of work demonstrating the behavioral importance of NAc DA release (Wise 2008; Volkow et al. 2017). Because all drugs of abuse lead to DA release in the NAc, as does intracranial electrical stimulation of brain sites that support self-stimulation, initial conceptualizations of the role of NAc DA release suggested that it contributes to instrumental conditioning because it signals "reward" as a direct consequence of the generation of a pleasurable experience (Wise 2008; Volkow et al. 2017). This simple concept was subsequently questioned in part because lesions of DA projections to the NAc impaired the willingness of rats to perform work for larger food rewards while not affecting their hedonic responses (Salamone et al. 1994; Berridge and Robinson 1998). In addition, it became apparent that humans will continue using drugs of abuse even when the acute experience of the drug is no longer pleasurable. These kinds of observations led to the influential idea that DA release in the NAc encodes "incentive salience" (Berridge and Robinson 1998) and that it is important to separate the neural circuit mechanisms that mediate motivation from those that mediate pleasure (Volkow et al. 2017).

Arguably the most influential idea about the functional role of NAc DA release is based on classic in vivo electrophysiological recordings in nonhuman primates, suggesting that midbrain DA neurons encode a bidirectional 
reward prediction error (RPE) signal, which is critical for many forms of instrumental learning (Schultz et al. 1997; Schultz 2016). Specifically, increases in DA neuron firing occur in response to a conditioned stimulus as it is learned to predict a reward, as well as when a better than expected reward occurs after the conditioned stimulus. In contrast, decreases in firing occur when an expected reward does not occur, perhaps signaling "disappointment." In addition to the studies that directly recorded midbrain DA neuron activity (Schultz 2016), several investigations measuring subsecond DA transients in the NAc using fast scan cyclic voltammetry (FSCV) are consistent with this hypothesis (Day et al. 2007; Roitman et al. 2008; Wassum et al. 2013). Furthermore, optogenetic activation of VTA DA neurons and their inputs in the NAc were found to be reinforcing in that these manipulations are sufficient to drive instrumental conditioning (Tsai et al. 2009; Witten et al. 2011) in a manner that is consistent with the RPE hypothesis (Steinberg et al. 2013).

A limitation of the heuristically useful RPE hypothesis of DA neuron function is that it routinely treats all midbrain DA neurons as a homogeneous population. This view does not incorporate the increasing body of evidence that midbrain DA neurons in general, and VTA DA neurons specifically, are heterogeneous in that they project to different targets, show distinct electrophysiological and molecular properties, and can respond to aversive as well as reinforcing stimuli (Lammel et al. 2008, 2011, 2012, 2014; Bromberg-Martin et al. 2010; Cohen et al. 2012). Indeed, application of modern monosynaptic viral tracing techniques in mice demonstrates that different subpopulations of both VTA and substantia nigra pars compacta (SNpc) DA neurons are embedded in different circuits with distinct input-output relationships (Beier et al. 2015; Lerner et al. 2015; Menegas et al. 2015). For example, VTA DA neurons projecting to the lateral NAc receive substantially more projections from anterior regions of the cortex including the PFC, whereas VTA DA neurons projecting to the medial NAc receive a greater proportion of their inputs from the dorsal raphe nucleus (Beier et al. 2015).

Further evidence for the complexity of DA action in the NAc derives from work studying the modulation of VTA DA neuron activity in mouse depression models. In mice susceptible to depression-related behaviors following social defeat stress, VTA DA neuron phasic firing has been reported to increase (Krishnan et al. 2007; Cao et al. 2010). In support of this increase being causally related to the depression phenotype, rather than a compensatory response, optogenetic activation of the VTA DA neurons that project to NAc induced susceptibility for social avoidance and anhedonia, whereas inhibition of these neurons made previously susceptible mice resilient to social defeat stress (Chaudhury et al. 2013; Walsh et al. 2014). However, in contrast to these findings, phasic stimulation of VTA DA neurons reversed a depression-related symptom caused by a chronic mild stress protocol and this reversal required DA action in the NAc (Tye et al. 2013). These disparate results, which derive from different rodent models of depression, are not easy to reconcile without evoking great complexity in how VTA DA neuron-mediated modulation of NAc circuitry changes in response to the different forms of stress used to cause "depression."

It is important to remember that the modulation of NAc activity by DA is bidirectional in that NAc MSNs send direct, monosynaptic projections to the VTA, which form synapses on both GABAergic interneurons and DA neurons (Xia et al. 2011; Bocklisch et al. 2013; Edwards et al. 2017; Yang et al. 2018). An influential hypothesis about the complex relationship between ventral and dorsal striatum and midbrain DA regions proposes that they are hierarchically organized in parallel reciprocal circuits and constitute an ascending spiral moving from the NAc shell toward the dorsal striatum (Nauta et al. 1978; Haber et al. 2000; Haber and Knutson 2010). This pattern of connectivity is often referred to as "striatonigral spiraling" (Haber et al. 2000) and has been suggested to play an important role both in the computation of RPEs (Keiflin and Janak 2015) and in addiction by contributing to the transition from initial encoding of the rewarding drug experience to the habitual behaviors underlying the compulsive seeking of drugs (Volkow et al. 2006; Vollstadt-Klein et al. 2010; Willuhn et al. 2012; Everitt and Robbins 2016).

Recent work on the reciprocal connectivity between VTA and NAc using a combination of state-of-the-art techniques revealed two parallel circuits: one from medial shell NAc D1 MSNs, which synapse on medial VTA DA neurons that project back to the medial NAc, and the other from lateral shell NAc D1 MSNs, which synapse on VTA GABAergic interneurons, leading to disinhibition of DA neurons projecting back to the NAc lateral shell (Fig. 2; Yang et al. 2018). As a consequence of this connectivity, optogenetic stimulation of lateral shell NAc D1 MSN terminals in VTA increases DA neuron activity and promotes reward-related behaviors, whereas activation of the medial shell NAc inputs inhibits DA neurons and suppresses behavioral output (Yang et al. 2018). These different populations of inhibitory inputs onto VTA DA and GABA cells also appear to activate different subtypes of $\mathrm{GABA}$ receptors (i.e., $\mathrm{GABA}_{\mathrm{A}}$ or $\mathrm{GABA}_{\mathrm{B}}$ receptors) (Edwards et al. 2017; Yang et al. 2018), providing additional complexity to the reciprocal interactions between VTA and NAc.

A critical question is how local DA release modifies NAc neural activity to cause its profound behavioral effects. Surprisingly, we have little information on this topic and no satisfying model of exactly how DA release changes NAc neural activity to cause reinforcement in a manner that drives instrumental conditioning and incentive salience. Furthermore, we have limited understanding of how the effects of DA on NAc activity change in models of pathological conditions, such as addiction and depression. Simple ideas include the hypothesis that DA acting on D1 receptors increases MSN excitability, whereas D2 receptor activation leads to a decrease in MSN excitability (Bromberg-Martin et al. 2010; Lobo and Nestler 2011). DA also depresses excitatory and inhibitory synaptic transmission in the NAc (Nicola and Malenka 1997; Nicola et al. 2000), at least in part by reducing lateral inhibition between MSNs (Dobbs et al. 2016). Although application of psychostimulant drugs has been used to evaluate the electro- 

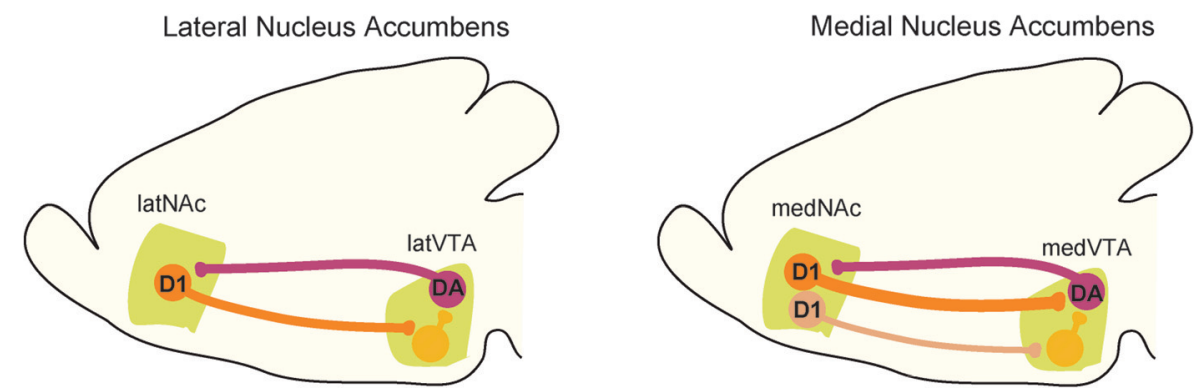

Figure 2. Diagram of proposed differences between circuitry of medial and lateral nucleus accumbens emphasizing differences in connectivity onto ventral tegmental area (VTA) GABAergic interneurons and dopamine (DA) neurons. (Modified from Yang et al. 2018.)

physiological consequences of enhancing endogenous DA levels in vivo and in vitro, the consequences of more physiological, action-potential evoked endogenous DA release on NAc MSN activity has not been extensively examined (e.g., during optogenetic induced release of DA). The regional complexity of the NAc discussed above highlights an additional challenge in elucidating the detailed neural mechanisms by which DA release influences behavior. We anticipate that the application of recently developed techniques to record activity from identified populations of NAc neurons, as done in dorsal striatum (Parker et al. 2018), will provide important information regarding the actions of DA. However, to generate meaningful hypotheses from such data about how DA action in the NAc elicits robust behavioral changes, it will be necessary to establish the input-output connectivity of each cell ensemble and clarify their molecular and electrophysiological properties.

\section{SEROTONIN ACTION IN THE NUCLEUS ACCUMBENS}

Arguably the neuromodulator that has received the most attention after DA is serotonin (5-HT), which like DA has been implicated in a wide range of adaptive and pathological behaviors (Müller and Jacobs 2010). Innervation of the striatum by 5-HT-containing inputs was first shown in the mid-1960s (Dahlström and Fuxe 1964, 1965), but it was primarily the discovery that antidepressant drugs act by inhibiting 5-HT transporter function (Nestler et al. 2015) that refocused attention on this neuromodulator. Recently, modern circuit elucidation tools have been applied to dissecting the anatomy and functions of the major 5-HT projection neuron populations in the dorsal raphe and median raphe nuclei (Ogawa et al. 2014; Pollak Dorocic et al. 2014; Weissbourd et al. 2014; Ren et al. 2018). These studies suggest that, like midbrain DA neurons, midbrain 5-HT neurons are heterogeneous and can be defined, in part, by their input-output connectivity. Consistent with this heterogeneity, dorsal raphe 5-HT neuron manipulations and recordings suggest complex roles in a range of behaviors related to cognition and motivation (Liu et al. 2014; Cohen et al. 2015; Brodsky et al. 2016; Li et al. 2016; You et al. 2016; Ren et al. 2018).
Only a small number of studies have attempted to examine the consequences of 5-HT release specifically in the NAc. Chemogenetic activation of 5-HT inputs in the NAc was reported to prevent cocaine elicited conditioned place preference and also decrease immobility time in the tail suspension test (You et al. 2016). On the other hand, overexpression of 5-HT6 receptors in NAc D2 MSNs appeared to increase the subjects' sensitivity to the reinforcing properties of cocaine (Brodsky et al. 2016). Although intriguing, these results are difficult to incorporate into any coherent hypothesis about the behavioral functions of 5HT release in the NAc.

Work from our laboratory suggests that 5 -HT release in the NAc may have a particularly important role in promoting sociability and nonaggressive social explorations. Using a social conditioned place preference assay to assess the reinforcing component of social interactions, previous work suggested that oxytocin action in the NAc was required for social reward (Dölen et al. 2013). Surprisingly, oxytocin appeared to act by promoting the release of $5-\mathrm{HT}$ in the NAc by activating presynaptic oxytocin receptors on the terminals of dorsal raphe 5-HT inputs in the NAc (Fig. 3). Consistent with a critical role of 5-HT in the NAc in social behaviors, bidirectional optogenetic manipulation

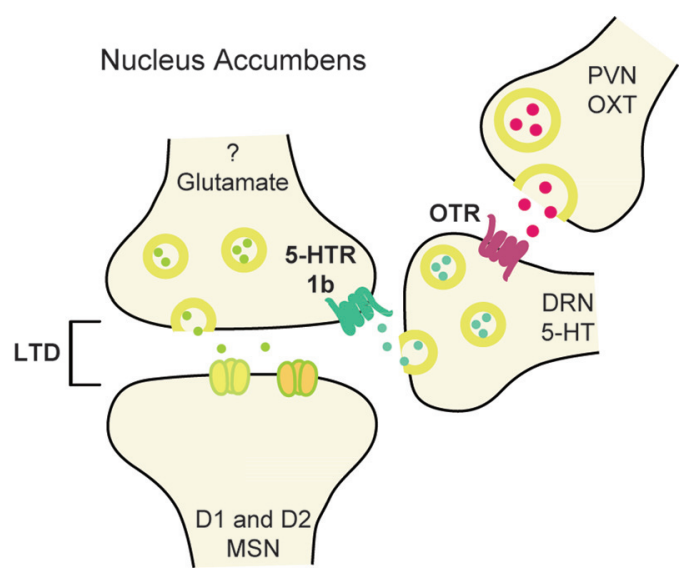

Figure 3. Model of the interactions of oxytocin (OXT) and serotonin $(5-\mathrm{HT})$ in the nucleus accumbens in a manner that promotes sociability and social reward by generating long-term depression at excitatory synapses on D1 and D2 MSNs. (Modified from Dölen et al. 2013.) 


\section{Sert-cre mice: DR-to-NAc terminals}

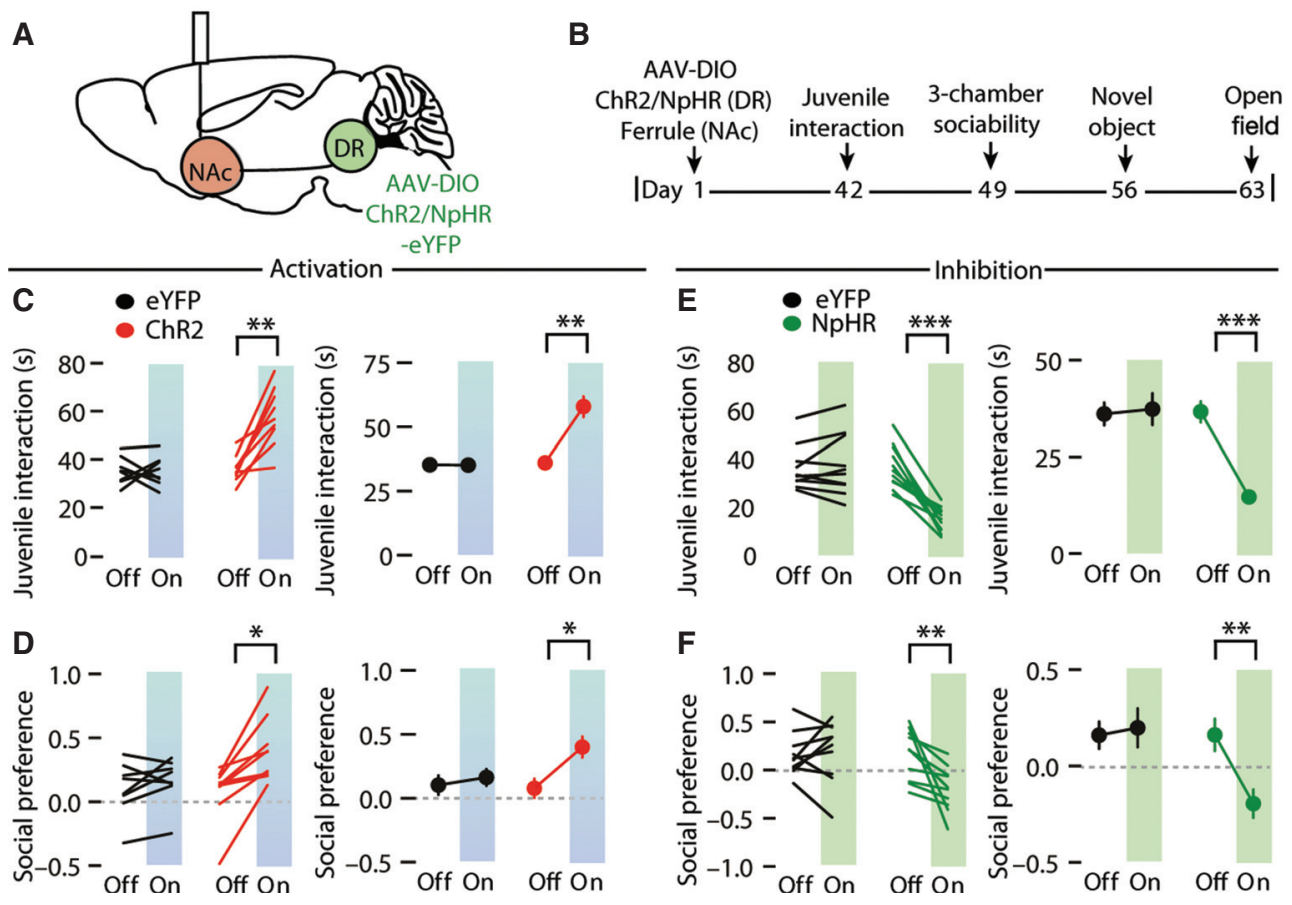

Figure 4. Bidirectional optogenetic modulation of dorsal raphe 5-HT neuron inputs in the nucleus accumbens bidirectionally influences sociability in two different assays. (A) Schematic of optogenetic manipulation. $(B)$ Time line of experiments. $(C, D)$ Quantification of juvenile interaction $(C)$ and three-chamber sociability $(D)$ assays in optogenetic activation experiments using ChR2 along with eYFP controls. Left panels show results from individual subjects; right panels show mean \pm SEM. $(E, F)$ Optogenetic inhibition experiments using NpHR along with eYFP controls. (Reprinted, with permission, from Walsh et al. 2018.)

of 5-HT input activity in the NAc bidirectionally influenced sociability in two different assays (Fig. 4; Walsh et al. 2018). Furthermore, 5-HT release in the NAc rescued sociability deficits in an autism mouse model via the activation of 5-HT1b receptors, the activation of which depresses excitatory transmission at unknown inputs onto NAc D1 and D2 MSNs (Fig. 3; Dölen et al. 2013; Walsh et al. 2018).

Importantly, in marked contrast to the consequences of activating DA inputs in the NAc, activation of 5-HT inputs in the NAc does not generate instrumental or Pavlovian conditioning; that is, 5-HT release in the NAc, unlike DA release, is not acutely reinforcing (Walsh et al. 2018). These results indicate that the modulation of NAc neural activity by DA and 5-HT must be significantly different. The sources of these differences are unknown and will require a large amount of work to be elucidated. Some key questions that need to be addressed to achieve further understanding of the differences in the behavioral consequences of DA and 5-HT release in the NAc include: Are similar or distinct NAc neuronal ensembles affected by DA and 5-HT release from the VTA and dorsal raphe nucleus, respectively? Exactly how does NAc D1 and D2 MSN activity change during increases in DA and 5-HT: Can any principles be discerned? Which DA and 5-HT receptor subtypes are activated by endogenous DA and 5-HT and where are these located? How do the effects of DA and 5HT on NAc activity change in various models of psychopathology, such as addiction and depression?

\section{PEPTIDE MODULATION OF NUCLEUS ACCUMBENS}

In addition to being strongly influenced by classic neuromodulators such as DA and 5-HT, the NAc is also affected by families of neuropeptides, which are too often neglected (Arrigoni and Saper 2014). Among the most prominent of these are the opioid peptides dynorphin and enkephalin, which preferentially activate $\kappa$-opioid and $\mu$-opioid receptors, respectively. As mentioned above, $\mu$-opioid receptors appear to be preferentially expressed in patch compartments and minimally expressed in matrix (Gerfen 1992; Crittenden and Graybiel 2011; Brimblecombe and Cragg 2017). $\kappa$-opioid receptors are found throughout the NAc on MSNs themselves as well as on presynaptic glutamatergic and neuromodulatory inputs (Fallon and Leslie 1986; Mansour et al. 1994; Lalanne et al. 2014; Brooks and O'Donnell 2017; Tejeda et al. 2017). The electrophysiological and behavioral actions of $\mu$-opioid and $\kappa$-opioid receptors in the NAc are complicated, although they clearly have powerful influences in a broad range of motivated behaviors influenced by emotionally salient stimuli.

Of particular interest is the suggestion that there is anatomical segregation of opioid signaling in the NAc beyond the patch-matrix distinction. Meticulous work using microinjections of pharmacological agents showed the presence of a "hedonic hotspot" concentrated in the rostrodorsal quadrant of the medial NAc shell, where activa- 
tion of several types of opioid receptors increased hedonic responses to sucrose. Surprisingly the same types of opioid-receptor stimulation in the caudal NAc suppressed reward reactions and was proposed to constitute a "hedonic coldspot" (Berridge and Kringelbach 2015). Similarly, optogenetic activation of dynorphinergic cells in different subregions of the NAc (i.e., dorsal vs. ventral) caused behaviors with opposite valence (i.e., rewarding vs. aversive) (Al-Hasani et al. 2015). Clearly, much work needs to be done to elucidate the anatomical, molecular, and physiological differences between these NAc regions so a more comprehensive understanding of their behavioral differences can be ascertained.

Oxytocin is another peptide with important actions in the NAc. Oxytocinergic neurons in the PVN of the hypothalamus send direct projections to both the NAc and VTA (Dölen et al. 2013; Hung et al. 2017). As mentioned above, oxytocin release in the NAc promotes social reward by enhancing NAc 5-HT release, which activates 5 -HT1b receptors that in turn reduce excitatory synaptic responses generated by unknown sets of inputs (Fig. 3; Dölen et al. 2013; Walsh et al. 2018). Stimulation of PVN oxytocin neurons using chemogenetic manipulation was also found to promote social reward, although it was suggested that this was caused by NAc accumulation of the endocannabinoid, anandamide, which like 5-HT, activates presynaptic receptors that depress excitatory synaptic transmission (Wei et al. 2015). In the VTA, oxytocin enhances the excitability of a subset of DA neurons that project to the NAc, thereby enhancing NAc DA release (Hung et al. 2017).

Three other neuropeptides worth mentioning are galanin, melanocortin, and orexin. Galanin receptor-1-triggered depression of excitatory synaptic transmission in NAc D2 MSNs was required for the decreased motivation caused by two different models of chronic pain (Schwartz et al. 2014). In contrast, depression of excitatory transmission in NAc D1 MSNs due to activation of melanocortin 4 receptors was required for the anhedonia caused by severe chronic stress (Lim et al. 2012). A recent study following up on these findings revealed that MC4Rs may be involved in attributing negative valence to aversive states (Klawonn et al. 2018). Finally, orexin also appears to influence NAc function in that orexin-mediated activation of NAc D2 MSNs is critical for innate risk avoidance (Blomeley et al. 2018). Orexin also increases the firing of NAc-projecting VTA DA neurons (Baimel et al. 2017), thereby providing an indirect mechanism by which orexin may influence NAc activity.

\section{CONCLUSION}

Recent advances in techniques that facilitate identification and manipulation of brain circuits have made it possible to functionally investigate neural ensembles based on their genetic profile as well as on their input and output characteristics. Application of these methods over the last decade has made it clear that circuitry involving the NAc is far more heterogeneous and complicated than previously envisioned. Furthermore, it has become clear that NAc activity is influenced in behaviorally important ways by a range of modulators including DA, 5-HT, and a host of neuropeptides. The functioning of NAc circuitry is also not static but dramatically altered by experiences, which are commonly used to model disease states such as addiction and depression. Throughout this review, we mention some of the many gaps in our current knowledge of NAc circuitry and function; addressing these gaps may seem daunting. However, by continuing to apply recently developed and new methods as they become available in creative and rigorous manners, we are confident that important advances in our understanding of NAc circuit function will be made. Such advances will facilitate a more sophisticated understanding of the many adaptive and pathological behavioral and cognitive functions in which the NAc participates.

\section{ACKNOWLEDGMENTS}

We gratefully acknowledge the scientists who performed the research described in this review. A.M.K. was supported by the Knut and Alice Wallenberg Foundation. R.C.M. was supported by grants from NIDA (DA008227, DA042012) and the Simons Foundation Autism Research Initiative (Award 305112).

\section{REFERENCES}

Al-Hasani R, McCall JG, Shin G, Gomez AM, Schmitz GP, Bernardi JM, Pyo CO, Park SI, Marcinkiewcz CM, Crowley NA, et al. 2015. Distinct subpopulations of nucleus accumbens dynorphin neurons drive aversion and reward. Neuron 87: 1063-1077. doi:10.1016/j.neuron.2015.08.019

Arrigoni E, Saper CB. 2014. What optogenetic stimulation is telling us (and failing to tell us) about fast neurotransmitters and neuromodulators in brain circuits for wake-sleep regulation. Curr Opin Neurobiol 29: 165-171. doi:10.1016/j.conb .2014.07.016

Baimel C, Lau BK, Qiao M, Borgland SL. 2017. Projectiontarget-defined effects of orexin and dynorphin on VTA dopamine neurons. Cell Rep 18: 1346-1355. doi:10.1016/j.celrep .2017 .01 .030

Barrientos C, Knowland D, Wu MMJ, Lilascharoen V, Huang KW, Malenka RC, Lim BK. 2018. Cocaine-induced structural plasticity in input regions to distinct cell types in nucleus accumbens. Biol Psychiatry 84: 893-904. doi:10.1016/ j.biopsych.2018.04.019

Beier KT, Steinberg EE, DeLoach KE, Xie S, Miyamichi K, Schwarz L, Gao XJ, Kremer EJ, Malenka RC, Luo L. 2015. Circuit architecture of VTA dopamine neurons revealed by systematic input-output mapping. Cell 162: 622-634. doi: 10.1016/j.cell.2015.07.015

Berridge KC, Kringelbach ML. 2015. Pleasure systems in the brain. Neuron 86: 646-664. doi:10.1016/j.neuron.2015.02 .018

Berridge KC, Robinson TE. 1998. What is the role of dopamine in reward: hedonic impact, reward learning, or incentive salience? Brain Res Brain Res Rev 28: 309-369. doi:10.1016/ S0165-0173(98)00019-8

Blomeley C, Garau C, Burdakov D. 2018. Accumbal D2 cells orchestrate innate risk-avoidance according to orexin signals. Nat Neurosci 21: 29-32. doi:10.1038/s41593-017-0023-y

Bock R, Shin JH, Kaplan AR, Dobi A, Markey E, Kramer PF, Gremel CM, Christensen CH, Adrover MF, Alvarez VA. 2013. Strengthening the accumbal indirect pathway promotes resil- 
ience to compulsive cocaine use. Nat Neurosci 16: 632-638. doi: 10.1038/nn.3369

Bocklisch C, Pascoli V, Wong JC, House DR, Yvon C, de Roo M, Tan KR, Lüscher C. 2013. Cocaine disinhibits dopamine neurons by potentiation of GABA transmission in the ventral tegmental area. Science 341: 1521-1525. doi:10.1126/science 1237059

Brimblecombe KR, Cragg SJ. 2017. The striosome and matrix compartments of the striatum: a path through the labyrinth from neurochemistry toward function. ACS Chem Neurosci 8: 235-242. doi:10.1021/acschemneuro.6b00333

Britt JP, Benaliouad F, McDevitt RA, Stuber GD, Wise RA, Bonci A. 2012. Synaptic and behavioral profile of multiple glutamatergic inputs to the nucleus accumbens. Neuron 76: 790-803. doi:10.1016/j.neuron.2012.09.040

Brodsky M, Gibson AW, Smirnov D, Nair SG, Neumaier JF. 2016. Striatal 5-HT6 receptors regulate cocaine reinforcement in a pathway-selective manner. Neuropsychopharmacology 41: 2377-2387. doi:10.1038/npp.2016.45

Bromberg-Martin ES, Matsumoto M, Hikosaka O. 2010. Dopamine in motivational control: rewarding, aversive, and alerting. Neuron 68: 815-834. doi:10.1016/j.neuron.2010.11.022

Brooks JM, O’Donnell P. 2017. $\kappa$ opioid receptors mediate heterosynaptic suppression of hippocampal inputs in the rat ventral striatum. $J$ Neurosci 37: 7140-7148. doi:10.1523/JNEU ROSCI.0876-17.2017

Calipari ES, Bagot RC, Purushothaman I, Davidson TJ, Yorgason JT, Pena CJ, Walker DM, Pirpinias ST, Guise KG, Ramakrishnan C, et al. 2016. In vivo imaging identifies temporal signature of D1 and D2 medium spiny neurons in cocaine reward. Proc Natl Acad Sci 113: 2726-2731. doi:10.1073/ pnas. 1521238113

Cao JL, Covington HE III, Friedman AK, Wilkinson MB, Walsh JJ, Cooper DC, Nestler EJ, Han MH. 2010. Mesolimbic dopamine neurons in the brain reward circuit mediate susceptibility to social defeat and antidepressant action. J Neurosci 30: 16453-16458. doi:10.1523/JNEUROSCI.3177-10.2010

Chaudhury D, Walsh JJ, Friedman AK, Juarez B, Ku SM, Koo JW, Ferguson D, Tsai HC, Pomeranz L, Christoffel DJ, et al. 2013. Rapid regulation of depression-related behaviours by control of midbrain dopamine neurons. Nature 493: 532536. doi:10.1038/nature11713

Choi JH, Sim SE, Kim JI, Choi DI, Oh J, Ye S, Lee J, Kim T, Ko HG, Lim CS, et al. 2018. Interregional synaptic maps among engram cells underlie memory formation. Science 360: 430435. doi:10.1126/science.aas 9204

Chuhma N, Mingote S, Moore H, Rayport S. 2014. Dopamine neurons control striatal cholinergic neurons via regionally heterogeneous dopamine and glutamate signaling. Neuron 81: 901-912. doi:10.1016/j.neuron.2013.12.027

Cohen JY, Haesler S, Vong L, Lowell BB, Uchida N. 2012. Neuron-type-specific signals for reward and punishment in the ventral tegmental area. Nature 482: 85-88. doi:10.1038/ nature 10754

Cohen JY, Amoroso MW, Uchida N. 2015. Serotonergic neurons signal reward and punishment on multiple timescales. Elife $\mathbf{4}$. doi:10.7554/eLife.06346

Creed M, Pascoli VJ, Lüscher C. 2015. Addiction therapy. Refining deep brain stimulation to emulate optogenetic treatment of synaptic pathology. Science 347: 659-664. doi:10.1126/ science. 1260776

Creed M, Ntamati NR, Chandra R, Lobo MK, Lüscher C. 2016. Convergence of reinforcing and anhedonic cocaine effects in the ventral pallidum. Neuron 92: 214-226. doi:10.1016/ j.neuron.2016.09.001

Crittenden JR, Graybiel AM. 2011. Basal ganglia disorders associated with imbalances in the striatal striosome and matrix compartments. Front Neuroanat 5: 59. doi:10.3389/fnana .2011 .00059

Dahlström A, Fuxe K. 1964. Evidence for the existence of monoamine-containing neurons in the central nervous system. I. Demonstration of monoamines in the cell bodies of brain stem neurons. Acta Physiol Scand Suppl 232: 1-55.
Dahlström A, Fuxe K. 1965. Evidence for the existence of monoamine neurons in the central nervous system. II. Experimentally induced changes in the intraneuronal amine levels of bulbospinal neuron systems. Acta Physiol Scand Suppl 247: $1-36$.

Danjo T, Yoshimi K, Funabiki K, Yawata S, Nakanishi S. 2014. Aversive behavior induced by optogenetic inactivation of ventral tegmental area dopamine neurons is mediated by dopamine D2 receptors in the nucleus accumbens. Proc Natl Acad Sci 111: 6455-6460. doi:10.1073/pnas.1404323111

Day JJ, Roitman MF, Wightman RM, Carelli RM. 2007. Associative learning mediates dynamic shifts in dopamine signaling in the nucleus accumbens. Nat Neurosci 10: 1020-1028. doi: $10.1038 / \mathrm{nn} 1923$

DeLong MR, Benabid AL. 2014. Discovery of high-frequency deep brain stimulation for treatment of Parkinson disease: 2014 Lasker Award. JAMA 312: 1093-1094. doi:10.1001/ jama.2014.11132

Di Chiara G. 2002. Nucleus accumbens shell and core dopamine: differential role in behavior and addiction. Behav Brain Res 137: 75-114. doi:10.1016/S0166-4328(02)00286-3

Di Chiara G, Imperato A. 1988. Drugs abused by humans preferentially increase synaptic dopamine concentrations in the mesolimbic system of freely moving rats. Proc Natl Acad Sci 85: 5274-5278. doi:10.1073/pnas.85.14.5274

Dobbs LK, Kaplan AR, Lemos JC, Matsui A, Rubinstein M, Alvarez VA. 2016. Dopamine regulation of lateral inhibition between striatal neurons gates the stimulant actions of cocaine. Neuron 90: 1100-1113. doi:10.1016/j.neuron.2016 .04 .031

Dölen G, Darvishzadeh A, Huang KW, Malenka RC. 2013. Social reward requires coordinated activity of nucleus accumbens oxytocin and serotonin. Nature 501: 179-184. doi:10.1038/ nature 12518

Dreyer JK, Vander Weele CM, Lovic V, Aragona BJ. 2016. Functionally distinct dopamine signals in nucleus accumbens core and shell in the freely moving rat. $J$ Neurosci 36: 98-112. doi:10.1523/JNEUROSCI.2326-15.2016

Edwards NJ, Tejeda HA, Pignatelli M, Zhang S, McDevitt RA, Wu J, Bass CE, Bettler B, Morales M, Bonci A. 2017. Circuit specificity in the inhibitory architecture of the VTA regulates cocaine-induced behavior. Nat Neurosci 20: 438-448. doi: 10.1038/nn.4482

Everitt BJ, Robbins TW. 2016. Drug addiction: updating actions to habits to compulsions ten years on. Annu Rev Psychol 67: 23-50. doi:10.1146/annurev-psych-122414-033457

Fallon JH, Leslie FM. 1986. Distribution of dynorphin and enkephalin peptides in the rat brain. J Comp Neurol 249: 293336. doi: $10.1002 / \mathrm{cne} .902490302$

Francis TC, Lobo MK. 2017. Emerging role for nucleus accumbens medium spiny neuron subtypes in depression. Biol Psychiatry 81: 645-653. doi:10.1016/j.biopsych.2016.09.007

Francis TC, Chandra R, Friend DM, Finkel E, Dayrit G, Miranda J, Brooks JM, Iñiguez SD, O’Donnell P, Kravitz A, et al. 2015. Nucleus accumbens medium spiny neuron subtypes mediate depression-related outcomes to social defeat stress. Biol Psychiatry 77: 212-222. doi:10.1016/j.biopsych .2014.07.021

Gerfen CR. 1992. The neostriatal mosaic: multiple levels of compartmental organization in the basal ganglia. Annu Rev Neurosci 15: 285-320. doi:10.1146/annurev.ne.15.030192 .001441

Gerfen CR, Herkenham M, Thibault J. 1987. The neostriatal mosaic: II. Patch- and matrix-directed mesostriatal dopaminergic and non-dopaminergic systems. J Neurosci 7: 3915-3934. doi:10.1523/JNEUROSCI.07-12-03915.1987

Gibson GD, Prasad AA, Jean-Richard-Dit-Bressel P, Yau JOY, Millan EZ, Liu Y, Campbell EJ, Lim J, Marchant NJ, Power JM, et al. 2018. Distinct accumbens shell output pathways promote versus prevent relapse to alcohol seeking. Neuron 98: 512-520.e6. doi:10.1016/j.neuron.2018.03.033

Gore BB, Zweifel LS. 2013. Genetic reconstruction of dopamine D1 receptor signaling in the nucleus accumbens facilitates 
natural and drug reward responses. J Neurosci 33: 8640-8649. doi:10.1523/JNEUROSCI.5532-12.2013

Haber SN, Knutson B. 2010. The reward circuit: linking primate anatomy and human imaging. Neuropsychopharmacology 35: 4-26. doi:10.1038/npp.2009.129

Haber SN, Fudge JL, McFarland NR. 2000. Striatonigrostriatal pathways in primates form an ascending spiral from the shell to the dorsolateral striatum. $J$ Neurosci 20: 2369-2382. doi: 10.1523/JNEUROSCI.20-06-02369.2000

Heinsbroek JA, Neuhofer DN, Griffin WC III, Siegel GS, Bobadilla AC, Kupchik YM, Kalivas PW. 2017. Loss of plasticity in the D2-accumbens pallidal pathway promotes cocaine seeking. J Neurosci 37: 757-767. doi:10.1523/JNEUROSCI .2659-16.2016

Hung LW, Neuner S, Polepalli JS, Beier KT, Wright M, Walsh JJ, Lewis EM, Luo L, Deisseroth K, Dölen G, et al. 2017. Gating of social reward by oxytocin in the ventral tegmental area. Science 357: 1406-1411. doi:10.1126/science.aan4994

Ikemoto S. 2007. Dopamine reward circuitry: two projection systems from the ventral midbrain to the nucleus accumbensolfactory tubercle complex. Brain Res Rev 56: 27-78. doi 10.1016/j.brainresrev.2007.05.004

Jedynak J, Hearing M, Ingebretson A, Ebner SR, Kelly M, Fischer RA, Kourrich S, Thomas MJ. 2016. Cocaine and amphetamine induce overlapping but distinct patterns of AMPAR plasticity in nucleus accumbens medium spiny neurons. $\mathrm{Neu}$ ropsychopharmacology 41: 464-476. doi:10.1038/npp.2015 .168

Keiflin R, Janak PH. 2015. Dopamine prediction errors in reward learning and addiction: from theory to neural circuitry. Neuron 88: 247-263. doi:10.1016/j.neuron.2015.08.037

Klawonn AM, Fritz M, Nilsson A, Bonaventura J, Shionoya K, Mirrasekhian E, Karlsson U, Jaarola M, Granseth B, Blomqvist A, et al. 2018. Motivational valence is determined by striatal melanocortin 4 receptors. J Clin Invest 128: 3160 3170. doi:10.1172/JCI97854

Koob GF, Sanna PP, Bloom FE. 1998. Neuroscience of addiction. Neuron 21: 467-476. doi:10.1016/S0896-6273(00) 80557-7

Kravitz AV, Tye LD, Kreitzer AC. 2012. Distinct roles for direct and indirect pathway striatal neurons in reinforcement. Nat Neurosci 15: 816-818. doi:10.1038/nn.3100

Kreitzer AC, Malenka RC. 2008. Striatal plasticity and basal ganglia circuit function. Neuron 60: 543-554. doi:10.1016/ j.neuron.2008.11.005

Krishnan V, Han MH, Graham DL, Berton O, Renthal W, Russo SJ, Laplant Q, Graham A, Lutter M, Lagace DC, et al. 2007. Molecular adaptations underlying susceptibility and resistance to social defeat in brain reward regions. Cell 131: 391-404. doi:10.1016/j.cell.2007.09.018

Kupchik YM, Kalivas PW. 2017. The direct and indirect pathways of the nucleus accumbens are not what you think. Neuropsychopharmacology 42: 369-370. doi:10.1038/npp.2016 .160

Kupchik YM, Brown RM, Heinsbroek JA, Lobo MK, Schwartz DJ, Kalivas PW. 2015. Coding the direct/indirect pathways by D1 and D2 receptors is not valid for accumbens projections. Nat Neurosci 18: 1230-1232. doi:10.1038/nn.4068

Lalanne L, Ayranci G, Kieffer BL, Lutz PE. 2014. The $\kappa$ opioid receptor: from addiction to depression, and back. Front Psychiatry 5: 170. doi:10.3389/fpsyt.2014.00170

Lammel S, Hetzel A, Häckel O, Jones I, Liss B, Roeper J. 2008. Unique properties of mesoprefrontal neurons within a dual mesocorticolimbic dopamine system. Neuron 57: 760-773. doi:10.1016/j.neuron.2008.01.022

Lammel S, Ion DI, Roeper J, Malenka RC. 2011. Projectionspecific modulation of dopamine neuron synapses by aversive and rewarding stimuli. Neuron 70: 855-862. doi:10.1016/ j.neuron.2011.03.025

Lammel S, Lim BK, Ran C, Huang KW, Betley MJ, Tye KM, Deisseroth K, Malenka RC. 2012. Input-specific control of reward and aversion in the ventral tegmental area. Nature 491: 212-217. doi:10.1038/nature11527
Lammel S, Lim BK, Malenka RC. 2014. Reward and aversion in a heterogeneous midbrain dopamine system. Neuropharmacology 76: 351-359. doi:10.1016/j.neuropharm.2013.03.019

Lerner TN, Shilyansky C, Davidson TJ, Evans KE, Beier KT, Zalocusky KA, Crow AK, Malenka RC, Luo L, Tomer R, et al. 2015. Intact-brain analyses reveal distinct information carried by SNc dopamine subcircuits. Cell 162: 635-647. doi:10.1016/j.cell.2015.07.014

Li Y, Zhong W, Wang D, Feng Q, Liu Z, Zhou J, Jia C, Hu F, Zeng J, Guo Q, et al. 2016. Serotonin neurons in the dorsal raphe nucleus encode reward signals. Nat Commun 7: 10503. doi: 10.1038/ncomms 10503

Lim BK, Huang KW, Grueter BA, Rothwell PE, Malenka RC. 2012. Anhedonia requires MC4R-mediated synaptic adaptations in nucleus accumbens. Nature 487: 183-189. doi: 10.1038 /nature 11160

Liu Z, Zhou J, Li Y, Hu F, Lu Y, Ma M, Feng Q, Zhang JE, Wang $\mathrm{D}$, Zeng J, et al. 2014. Dorsal raphe neurons signal reward through 5-HT and glutamate. Neuron 81: 1360-1374. doi: 10.1016/j.neuron.2014.02.010

Lobo MK, Nestler EJ. 2011. The striatal balancing act in drug addiction: distinct roles of direct and indirect pathway medium spiny neurons. Front Neuroanat 5: 41

Lobo MK, Covington HE III, Chaudhury D, Friedman AK, Sun H, Damez-Werno D, Dietz DM, Zaman S, Koo JW, Kennedy PJ, et al. 2010. Cell type-specific loss of BDNF signaling mimics optogenetic control of cocaine reward. Science 330: 385-390. doi: $10.1126 /$ science. 1188472

Lüscher C. 2016. The emergence of a circuit model for addiction. Anпи Rev Neurosci 39: 257-276. doi:10.1146/annurev-neuro070815-013920

Lüscher C, Malenka RC. 2011. Drug-evoked synaptic plasticity in addiction: from molecular changes to circuit remodeling. Neuron 69: 650-663. doi:10.1016/j.neuron.2011. 01.017

Ma YY, Lee BR, Wang X, Guo C, Liu L, Cui R, Lan Y, BalcitaPedicino JJ, Wolf ME, Sesack SR, et al. 2014. Bidirectional modulation of incubation of cocaine craving by silent synapsebased remodeling of prefrontal cortex to accumbens projections. Neuron 83: 1453-1467. doi:10.1016/j.neuron.2014 .08 .023

MacAskill AF, Cassel JM, Carter AG. 2014. Cocaine exposure reorganizes cell type- and input-specific connectivity in the nucleus accumbens. Nat Neurosci 17: 1198-1207. doi: $10.1038 / \mathrm{nn} .3783$

Mansour A, Fox CA, Burke S, Meng F, Thompson RC, Akil H, Watson SJ. 1994. $\mu, \delta$, and $\kappa$ opioid receptor mRNA expression in the rat CNS: an in situ hybridization study. J Comp Neurol 350: 412-438. doi:10.1002/cne.903500307

Menegas W, Bergan JF, Ogawa SK, Isogai Y, Umadevi Venkataraju K, Osten P, Uchida N, Watabe-Uchida M. 2015. Dopamine neurons projecting to the posterior striatum form an anatomically distinct subclass. Elife 4: e10032. doi:10.7554/eLife .10032

Mogenson GJ, Jones DL, Yim CY. 1980. From motivation to action: functional interface between the limbic system and the motor system. Prog Neurobiol 14: 69-97. doi:10.1016/ 0301-0082(80)90018-0

Müller CP, Jacobs BL. 2010. Handbook of the behavioral neurobiology of serotonin. Elsevier, San Diego.

Nauta WJ, Smith GP, Faull RL, Domesick VB. 1978. Efferent connections and nigral afferents of the nucleus accumbens septi in the rat. Neuroscience 3: 385-401. doi:10.1016/03064522(78)90041-6

Nelson AB, Kreitzer AC. 2014. Reassessing models of basal ganglia function and dysfunction. Annu Rev Neurosci 37: 117-135. doi:10.1146/annurev-neuro-071013-013916

Nestler EJ. 2005. Is there a common molecular pathway for addiction? Nat Neurosci 8: 1445-1449. doi:10.1038/ nn1578

Nestler EJ, Hyman SE, Holtzman DM, Malenka RC. 2015. Molecular neuropharmacology - a foundation for clinical neuroscience, 3rd ed. McGraw-Hill Education, New York. 
Nicola SM. 2007. The nucleus accumbens as part of a basal ganglia action selection circuit. Psychopharmacology (Berl) 191: 521-550. doi:10.1007/s00213-006-0510-4

Nicola SM, Malenka RC. 1997. Dopamine depresses excitatory and inhibitory synaptic transmission by distinct mechanisms in the nucleus accumbens. $J$ Neurosci 17: 5697-5710. doi:10 .1523/JNEUROSCI.17-15-05697.1997

Nicola SM, Surmeier J, Malenka RC. 2000. Dopaminergic modulation of neuronal excitability in the striatum and nucleus accumbens. Annu Rev Neurosci 23: 185-215. doi:10.1146/ annurev.neuro.23.1.185

O’Connor EC, Kremer Y, Lefort S, Harada M, Pascoli V, Rohner C, Lüscher C. 2015. Accumbal D1R neurons projecting to lateral hypothalamus authorize feeding. Neuron 88: 553564. doi:10.1016/j.neuron.2015.09.038

O’Donnell P, Greene J, Pabello N, Lewis BL, Grace AA. 1999. Modulation of cell firing in the nucleus accumbens. Ann NY Acad Sci 877: 157-175. doi:10.1111/j.1749-6632.1999.tb 09267.x

Ogawa SK, Cohen JY, Hwang D, Uchida N, Watabe-Uchida M. 2014. Organization of monosynaptic inputs to the serotonin and dopamine neuromodulatory systems. Cell Rep 8: 11051118. doi:10.1016/j.celrep.2014.06.042

Otis JM, Namboodiri VM, Matan AM, Voets ES, Mohorn EP, Kosyk O, McHenry JA, Robinson JE, Resendez SL, Rossi MA, et al. 2017. Prefrontal cortex output circuits guide reward seeking through divergent cue encoding. Nature 543: 103107. doi:10.1038/nature21376

Parker JG, Marshall JD, Ahanonu B, Wu YW, Kim TH, Grewe BF, Zhang Y, Li JZ, Ding JB, Ehlers MD, et al. 2018. Diametric neural ensemble dynamics in parkinsonian and dyskinetic states. Nature 557: 177-182. doi:10.1038/s41586-0180090-6

Pascoli V, Turiault M, Lüscher C. 2011. Reversal of cocaineevoked synaptic potentiation resets drug-induced adaptive behaviour. Nature 481: 71-75. doi:10.1038/nature10709

Pascoli V, Terrier J, Espallergues J, Valjent E, O'Connor EC, Lüscher C. 2014. Contrasting forms of cocaine-evoked plasticity control components of relapse. Nature 509: 459-464. doi:10.1038/nature13257

Pollak Dorocic I, Fürth D, Xuan Y, Johansson Y, Pozzi L, Silberberg G, Carlén M, Meletis K. 2014. A whole-brain atlas of inputs to serotonergic neurons of the dorsal and median raphe nuclei. Neuron 83: 663-678. doi:10.1016/j.neuron.2014.07 .002

Prado L, Luis-Islas J, Sandoval OI, Puron L, Gil MM, Luna A, Arias-Garcia MA, Galarraga E, Simon SA, Gutierrez R. 2016. Activation of glutamatergic fibers in the anterior NAc shell modulates reward activity in the aNAcSh, the lateral hypothalamus, and medial prefrontal cortex and transiently stops feeding. J Neurosci 36: 12511-12529. doi:10.1523/JNEUROSCI $.1605-16.2016$

Reed SJ, Lafferty CK, Mendoza JA, Yang AK, Davidson TJ, Grosenick L, Deisseroth K, Britt JP. 2018. Coordinated reductions in excitatory input to the nucleus accumbens underlie food consumption. Neuron 99: 1260-1273.e4. doi:10.1016/ j.neuron.2018.07.051

Ren J, Friedmann D, Xiong J, Liu CD, Ferguson BR, Weerakkody T, DeLoach KE, Ran C, Pun A, Sun Y, et al. 2018. Anatomically defined and functionally distinct dorsal raphe serotonin sub-systems. Cell 175: 472-487.e20. doi:10.1016/ j.cell.2018.07.043

Reynolds SM, Berridge KC. 2008. Emotional environments retune the valence of appetitive versus fearful functions in nucleus accumbens. Nat Neurosci 11: 423-425. doi:10.1038/ nn2061

Roitman MF, Wheeler RA, Wightman RM, Carelli RM. 2008. Real-time chemical responses in the nucleus accumbens differentiate rewarding and aversive stimuli. Nat Neurosci 11: 13761377. doi: $10.1038 / \mathrm{nn} .2219$

Russo SJ, Nestler EJ. 2013. The brain reward circuitry in mood disorders. Nat Rev Neurosci 14: 609-625. doi:10.1038/ nrn3381
Russo SJ, Dietz DM, Dumitriu D, Morrison JH, Malenka RC, Nestler EJ. 2010. The addicted synapse: mechanisms of synaptic and structural plasticity in nucleus accumbens. Trends Neurosci 33: 267-276. doi:10.1016/j.tins.2010.02.002

Sackett DA, Saddoris MP, Carelli RM. 2017. Nucleus accumbens shell dopamine preferentially tracks information related to outcome value of reward. eNeuro 4: ENEURO.0058-17.2017. doi:10.1523/ENEURO.0058-17.2017

Saddoris MP, Sugam JA, Carelli RM. 2017. Prior cocaine experience impairs normal phasic dopamine signals of reward value in accumbens shell. Neuropsychopharmacology 42: 766-773. doi:10.1038/npp.2016.189

Salamone JD, Cousins MS, Bucher S. 1994. Anhedonia or anergia? Effects of haloperidol and nucleus accumbens dopamine depletion on instrumental response selection in a T-maze cost/ benefit procedure. Behav Brain Res 65: 221-229. doi:10.1016/ 0166-4328(94)90108-2

Schmidt HD, McFarland KN, Darnell SB, Huizenga MN, Sangrey GR, Cha JH, Pierce RC, Sadri-Vakili G. 2015. ADAR2dependent GluA2 editing regulates cocaine seeking. Mol Psychiatry 20: 1460-1466. doi:10.1038/mp.2014.134

Schultz W. 2016. Dopamine reward prediction-error signalling: a two-component response. Nat Rev Neurosci 17: 183-195. doi:10.1038/nrn.2015.26

Schultz W, Dayan P, Montague PR. 1997. A neural substrate of prediction and reward. Science 275: 1593-1599. doi:10.1126/ science.275.5306.1593

Schwartz N, Temkin P, Jurado S, Lim BK, Heifets BD, Polepalli JS, Malenka RC. 2014. Chronic pain. decreased motivation during chronic pain requires long-term depression in the nucleus accumbens. Science 345: 535-542. doi:10.1126/science .1253994

Scofield MD, Heinsbroek JA, Gipson CD, Kupchik YM, Spencer S, Smith AC, Roberts-Wolfe D, Kalivas PW. 2016. The nucleus accumbens: mechanisms of addiction across drug classes reflect the importance of glutamate homeostasis. Pharmacol Rev 68: 816-871. doi:10.1124/pr.116.012484

Steinberg EE, Keiflin R, Boivin JR, Witten IB, Deisseroth K, Janak PH. 2013. A causal link between prediction errors, dopamine neurons and learning. Nat Neurosci 16: 966-973. doi:10.1038/nn.3413

Stuber GD, Sparta DR, Stamatakis AM, van Leeuwen WA, Hardjoprajitno JE, Cho S, Tye KM, Kempadoo KA, Zhang F, Deisseroth K, et al. 2011. Excitatory transmission from the amygdala to nucleus accumbens facilitates reward seeking. Nature 475: 377-380. doi:10.1038/nature10194

Syed EC, Grima LL, Magill PJ, Bogacz R, Brown P, Walton ME. 2016. Action initiation shapes mesolimbic dopamine encoding of future rewards. Nat Neurosci 19: 34-36. doi:10.1038/nn .4187

Tejeda HA, Wu J, Kornspun AR, Pignatelli M, Kashtelyan V, Krashes MJ, Lowell BB, Carlezon WA Jr, Bonci A. 2017. Pathway- and cell-specific $\kappa$-opioid receptor modulation of excitation-inhibition balance differentially gates D1 and D2 accumbens neuron activity. Neuron 93: 147-163. doi: 10.1016/j.neuron.2016.12.005

Terrier J, Lüscher C, Pascoli V. 2016. Cell-type specific insertion of GluA2-lacking AMPARs with cocaine exposure leading to sensitization, cue-induced seeking, and incubation of craving. Neuropsychopharmacology 41: 1779-1789. doi:10.1038/npp .2015 .345

Trifilieff P, Feng B, Urizar E, Winiger V, Ward RD, Taylor KM, Martinez D, Moore H, Balsam PD, Simpson EH, et al. 2013. Increasing dopamine D2 receptor expression in the adult nucleus accumbens enhances motivation. Mol Psychiatry 18: 1025-1033. doi: $10.1038 / \mathrm{mp} .2013 .57$

Tsai HC, Zhang F, Adamantidis A, Stuber GD, Bonci A, de Lecea L, Deisseroth K. 2009. Phasic firing in dopaminergic neurons is sufficient for behavioral conditioning. Science 324: 10801084. doi: $10.1126 /$ science. 1168878

Tye KM, Mirzabekov JJ, Warden MR, Ferenczi EA, Tsai HC, Finkelstein J, Kim SY, Adhikari A, Thompson KR, Andalman AS, et al. 2013. Dopamine neurons modulate neural encoding 
and expression of depression-related behaviour. Nature 493: $537-541$.

Ungerstedt U. 1971. Stereotaxic mapping of the monoamine pathways in the rat brain. Acta Physiol Scand Suppl 367: 148. doi:10.1111/j.1365-201X.1971.tb10998.x

Volkow ND, Wang GJ, Telang F, Fowler JS, Logan J, Childress AR, Jayne M, Ma Y, Wong C. 2006. Cocaine cues and dopamine in dorsal striatum: mechanism of craving in cocaine addiction. J Neurosci 26: 6583-6588. doi:10.1523/JNEURO SCI.1544-06.2006

Volkow ND, Wise RA, Baler R. 2017. The dopamine motive system: implications for drug and food addiction. Nat Rev Neurosci 18: 741-752. doi:10.1038/nrn.2017.130

Vollstadt-Klein S, Wichert S, Rabinstein J, Bühler M, Klein O, Ende G, Hermann D, Mann K. 2010. Initial, habitual and compulsive alcohol use is characterized by a shift of cue processing from ventral to dorsal striatum. Addiction 105: 17411749. doi:10.1111/j.1360-0443.2010.03022.x

Walsh JJ, Friedman AK, Sun H, Heller EA, Ku SM, Juarez B, Burnham VL, Mazei-Robison MS, Ferguson D, Golden SA, et al. 2014. Stress and CRF gate neural activation of BDNF in the mesolimbic reward pathway. Nat Neurosci 17: 27-29. doi:10.1038/nn.3591

Walsh JJ, Christoffel DJ, Heifets BD, Ben-Dor GA, Selimbeyoglu A, Hung LW, Deisseroth K, Malenka RC. 2018. 5-HT release in nucleus accumbens rescues social deficits in mouse autism model. Nature 560: 589-594. doi:10.1038/s41586018-0416-4

Wassum KM, Ostlund SB, Loewinger GC, Maidment NT. 2013. Phasic mesolimbic dopamine release tracks reward seeking during expression of Pavlovian-to-instrumental transfer. Biol Psychiatry 73: 747-755. doi:10.1016/j.biopsych.2012. 12.005

Watabe-Uchida M, Zhu L, Ogawa SK, Vamanrao A, Uchida N. 2012. Whole-brain mapping of direct inputs to midbrain dopamine neurons. Neuron 74: 858-873. doi:10.1016/j.neuron .2012.03.017

Wei D, Lee D, Cox CD, Karsten CA, Peñagarikano O, Geschwind DH, Gall CM, Piomelli D. 2015. Endocannabinoid sig- naling mediates oxytocin-driven social reward. Proc Natl Acad Sci 112: 14084-14089. doi:10.1073/pnas.1509795112

Weissbourd B, Ren J, DeLoach KE, Guenthner CJ, Miyamichi K, Luo L. 2014. Presynaptic partners of dorsal raphe serotonergic and GABAergic neurons. Neuron 83: 645-662. doi:10.1016/ j.neuron.2014.06.024

Willuhn I, Burgeno LM, Everitt BJ, Phillips PE. 2012. Hierarchical recruitment of phasic dopamine signaling in the striatum during the progression of cocaine use. Proc Natl Acad Sci 109: 20703-20708. doi:10.1073/pnas.1213460109

Wise RA. 2008. Dopamine and reward: the anhedonia hypothesis 30 years on. Neurotox Res 14: 169-183. doi:10.1007/ BF03033808

Witten IB, Steinberg EE, Lee SY, Davidson TJ, Zalocusky KA, Brodsky M, Yizhar O, Cho SL, Gong S, Ramakrishnan C, et al. 2011. Recombinase-driver rat lines: tools, techniques, and optogenetic application to dopamine-mediated reinforcement. Neuron 72: 721-733. doi:10.1016/j.neuron.2011.10.028

Xia Y, Driscoll JR, Wilbrecht L, Margolis EB, Fields HL, Hjelmstad GO. 2011. Nucleus accumbens medium spiny neurons target non-dopaminergic neurons in the ventral tegmental area. J Neurosci 31: 7811-7816. doi:10.1523/JNEUROSCI $.1504-11.2011$

Yang H, de Jong JW, Tak Y, Peck J, Bateup HS, Lammel S. 2018. Nucleus accumbens subnuclei regulate motivated behavior via direct inhibition and disinhibition of VTA dopamine subpopulations. Neuron 97: 434-449.e4. doi:10.1016/j.neuron.2017 .12 .022

You IJ, Wright SR, Garcia-Garcia AL, Tapper AR, Gardner PD, Koob GF, David Leonardo E, Bohn LM, Wee S. 2016. 5-HT1A autoreceptors in the dorsal raphe nucleus convey vulnerability to compulsive cocaine seeking. Neuropsychopharmacology 41: 1210-1222. doi:10.1038/npp.2015.268

Zahm DS, Brog JS. 1992. On the significance of subterritories in the "accumbens" part of the rat ventral striatum. Neuroscience 50: 751-767. doi:10.1016/0306-4522(92)90202-D

Zhu Y, Wienecke CF, Nachtrab G, Chen X. 2016. A thalamic input to the nucleus accumbens mediates opiate dependence. Nature 530: 219-222. doi:10.1038/nature16954 


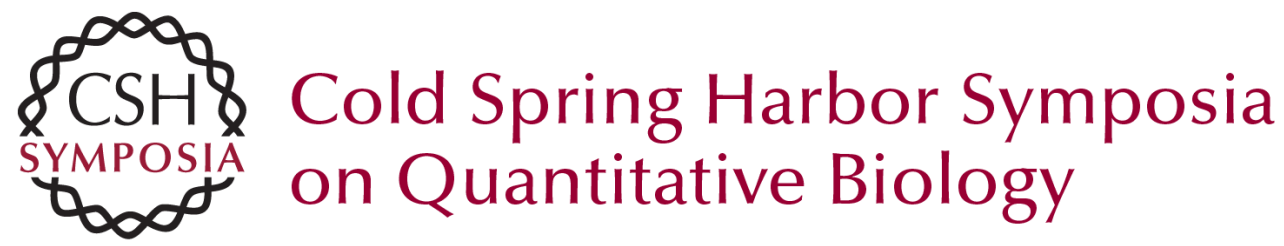

\section{Nucleus Accumbens Modulation in Reward and Aversion}

Anna M. Klawonn and Robert C. Malenka

Cold Spring Harb Symp Quant Biol 2018 83: 119-129 originally published online January 23, 2019

Access the most recent version at doi:10.1101/sqb.2018.83.037457

References This article cites 131 articles, 26 of which can be accessed free at: http://symposium.cshlp.org/content/83/119.full.html\#ref-list-1

Creative This article is distributed under the terms of the

Commons

License

http://creativecommons.org/licenses/by-nc/4.0/, which permits reuse and redistribution, except for commercial purposes, provided that the original author and source are credited.

Email Alerting Receive free email alerts when new articles cite this article - sign up in Service the box at the top right corner of the article or click here. 